\title{
Stages and Status of Vertical Transporting Process of Cd in Jiaozhou Bay
}

\author{
Dongfang Yang ${ }^{1,2,3, ~ a, ~ Q i ~ W a n g ~}{ }^{2}$, Haixia Li ${ }^{1,2}$, Xiaolong Zhang ${ }^{2}$ Jun Ding ${ }^{1,2}$ \\ ${ }^{1}$ Center for Accounting and Auditing Informatics, Xijing University, Xi’an 710123, China \\ ${ }^{2}$ Accountancy Shool, Xijing University, Xi'an 710123, China \\ ${ }^{3}$ North China Sea Environmental Monitoring Center, SOA, Qingdao 266033, China \\ adfyang_dfyang@126.com
}

Keywords: Cd, Transporting process, Stages, Status, Jiaozhou Bay

\begin{abstract}
Understanding the stages of transporting process of $\mathrm{Cd}$ in marine is essential to pollution control. This paper analyzed the stages and status of Cd's vertical transporting process in waters in Jiaozhou Bay during 1979-1983. Results showed that the vertical transporting process in waters in Jiaozhou Bay included three stages of 1) Cd was imported to the bay, 2) Cd was transported to surface waters, and 3) Cd was transported from surface waters to bottom waters. The vertical transporting process included six status of 1 ) the sources discharged a lot of $\mathrm{Cd}$ to the bay, and Cd contents in surface waters were higher than in bottom waters, 2) the input of Cd was increasing, and Cd contents in surface waters were still higher than in bottom waters, 3) the input of Cd continued, a big part of Cd was transported to bottom waters, and Cd contents in surface and bottom waters were closed, 4) the input of Cd was decreasing, and the sedimentation of Cd continued, and Cd contents in surface waters were lower than in bottom waters, 5) the input of Cd stopped, and the sedimentation of Cd continued, Cd contents in surface waters were little and were lower than in bottom waters, 6) the input of the input of Cd stopped, and the sedimentation of Cd stopped since Cd contents in surface waters were little, and Cd contents in surface and bottom waters were closed. These stages and status reveal the vertical transporting process of Cd clearly.
\end{abstract}

\section{Introduction}

Along with the rapid development of industry, a large amount of Cd-containing wastes were discharged to marine bays via sources of marine current, river flow, island top, atmosphere deposition, overland runoff and wharf, etc., and Cd pollution is one of the critical environmental issues in many marine bays [1-6]. Vertical transporting process is the key transporting process of pollutants in marine waters, and identifying the stages and status of pollutants in marine bays is one of the critical environmental issues, and understanding the stages of transporting process of Cd in marine is essential to pollution control [7-12].

Jiaozhou Bay is a semi-closed bay located in Shandong Province, eastern China, and had been polluted by various pollutants including Cd [7-12]. This paper analyzed the stages and status of Cd's vertical transporting process in waters in Jiaozhou Bay during 1979-1983. Results showed that the vertical transporting process could be defined into three stages and six stages, which were providing important basis information to scientific research and pollution control practice.

\section{Study area and data collection}

Jiaozhou Bay is located in the south of Shandong Province, eastern China $\left(35^{\circ} 55^{\prime}-36^{\circ} 18^{\prime} \mathrm{N}\right.$, $\left.120^{\circ} 04^{\prime}-120^{\circ} 23^{\prime} \mathrm{E}\right)$. The total area, average water depth and bay mouth width are $446 \mathrm{~km}^{2}, 7 \mathrm{~m}$ and $3 \mathrm{~km}$, respectively. This bay is connected to the Yellow Sea in the south. There are a dozen of rivers, and the majors are Dagu River, Haibo Rriver, Licun Rriver, and Loushan Rriver etc., all of which are seasonal rivers [13-14].

The investigation on Cd content in surface and bottom waters in Jiaozhou Bay was conducted in 
May, August, and November 1979, June, July and September 1980, April, August and November 1981, April, June, July and October 1982, and, May, September and November 1983, respectively [1-10]. Cd in surface waters was sampled and monitored follow by National Specification for Marine Monitoring (Fig. 1) [15].

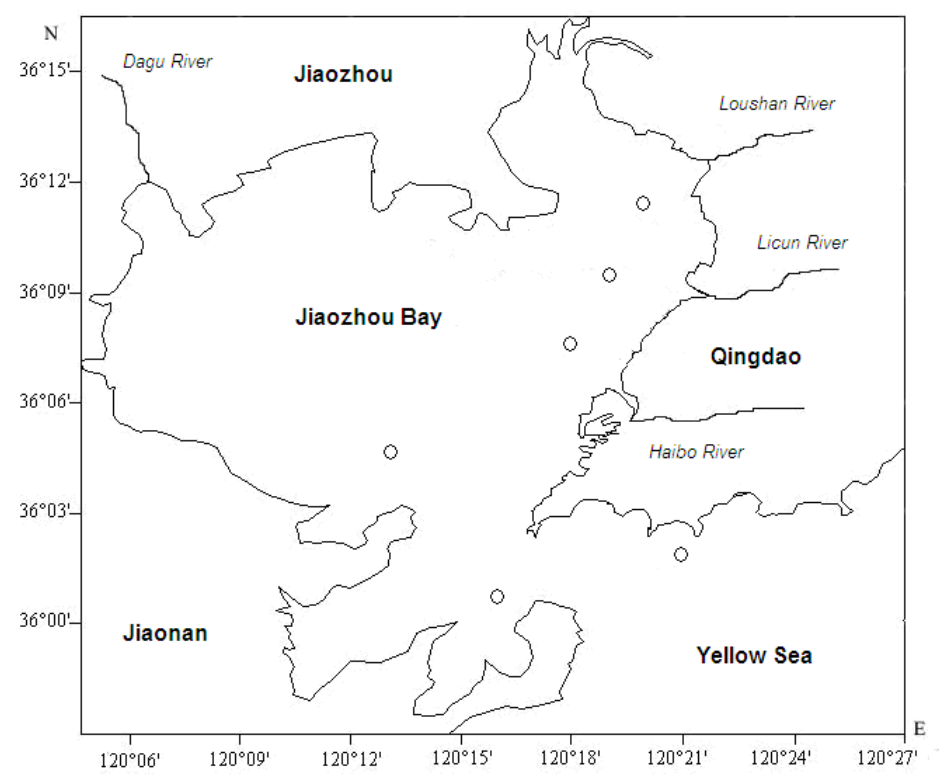

Fig. 1 Geographic location and sampling sites in Jiaozhou Bay

\section{Results and discussion}

\subsection{Variations of Cd contents in surface and bottom waters}

Cd contents in surface waters were determined by variations of Cd input from the sources, while Cd contents in bottom waters were productions of which in surface waters and water's effect [16-20]. Cd contents in surface and bottom waters in different months during 1979-1983 were listed in Table 1 to Table 5, respectively. It could be seen from Table 1 to Table 5 that in case of Cd contents in surface waters were high, Cd contents in bottom waters were also high, and in case of $\mathrm{Cd}$ content in surface waters were low, Cd contents in bottom waters were also low. Meanwhile, the variations of $\mathrm{Cd}$ contents in surface waters and bottom waters in different months were closed. Hence, it was confirmed that Cd contents in bottom waters were strongly impacted by Cd contents in surface waters by means of vertical transporting, which was determined by water's effect [16] that contained vertical water's effect [17] and vertical water's effect [18]. However, the different stages and status of this vertical transporting process needed to be further analyzed, and were provided in the following section.

Table 1 Cd contents in surface and bottom waters in Jiaozhou Bay 1979/ $\mu \mathrm{g} \mathrm{L}{ }^{-1}$

\begin{tabular}{|c|c|c|}
\hline Month & Surface water & Bottom waters \\
\hline May & $0.05-0.06$ & $0.03-0.07$ \\
\hline August & $0.01-0.06$ & $0.03-0.09$ \\
\hline November & $0.02-0.25$ & $0.01-0.02$ \\
\hline
\end{tabular}

Table 2 Cd contents in surface and bottom waters in Jiaozhou Bay 1980/ $\mathrm{g} \mathrm{L}^{-1}$

\begin{tabular}{|c|c|c|}
\hline Month & Surface water & Bottom waters \\
\hline June & $0.06-0.16$ & $0.10-0.32$ \\
\hline July & $0.08-0.48$ & $0.00-0.35$ \\
\hline September & $0.00-0.24$ & $0.00-0.17$ \\
\hline October & $0.00-0.00$ & $0.00-0.11$ \\
\hline
\end{tabular}


Table 3 Cd contents in surface and bottom waters in Jiaozhou Bay 1981/ $\mathrm{g} \mathrm{L}^{-1}$

\begin{tabular}{|c|c|c|}
\hline Month & Surface water & Bottom waters \\
\hline April & $0.00-0.14$ & $0.00-0.02$ \\
\hline August & $0.00-0.40$ & $0.00-0.13$ \\
\hline November & $0.00-0.005$ & $0.00-0.002$ \\
\hline
\end{tabular}

Table 4 Cd contents in surface and bottom waters in Jiaozhou Bay 1982/ $\mu \mathrm{g} \mathrm{L}{ }^{-1}$

\begin{tabular}{|c|c|c|}
\hline Month & Surface water & Bottom waters \\
\hline April & $0.11-0.38$ & $0.20-0.44$ \\
\hline July & $0.12-0.52$ & $0.13-0.24$ \\
\hline October & $0.32-0.53$ & $0.21-0.53$ \\
\hline
\end{tabular}

Table 5 Cd contents in surface and bottom waters in Jiaozhou Bay 1983/ $\mu \mathrm{g} \mathrm{L}{ }^{-1}$

\begin{tabular}{|c|c|c|}
\hline Month & Surface water & Bottom waters \\
\hline May & $0.09-0.41$ & $0.10-0.15$ \\
\hline September & $0.40-3.33$ & $0.67-2.00$ \\
\hline November & $0.10-1.50$ & $0.03-2.03$ \\
\hline
\end{tabular}

\subsection{Stages and status of the vertical transporting process of $\mathrm{Cd}$}

In according to the variations of Cd contents in surface and bottom waters and the analysis above, it could be defined that the vertical transporting process in waters in Jiaozhou Bay included three stages of 1) Cd was imported to the bay, 2) Cd was transported to surface waters, and 3) Cd was transported from surface waters to bottom waters. The three stages could be showed in a block diagram model (Fig. 2). Furthermore, the vertical transporting process included six status. First, the sources discharged a lot of Cd to the bay, and Cd contents in surface waters were higher than in bottom waters. Second, the input of Cd was increasing, and Cd contents in surface waters were still higher than in bottom waters. Third, the input of $\mathrm{Cd}$ was continue, a big part of Cd was transported to bottom waters, and Cd contents in surface and bottom waters were closed. Fourth, the input of Cd was decreasing, and the sedimentation of Cd was continue, and Cd contents in surface waters were lower than in bottom waters. Fifth, the input of Cd was stop, and the sedimentation of Cd was continue, Cd contents in surface waters were little and were lower than in bottom waters. Sixth, the input of the input of Cd was stop, and the sedimentation of Cd was stop since Cd contents in surface waters were little, and Cd contents in surface and bottom waters were closed. These stages and status were revealing the vertical transporting process of Cd clearly, and were consistent with the vertical transporting process of other pollutants such as hexachlorocyclohexane, $\mathrm{Hg}$ and $\mathrm{Cr}$ [16-20].

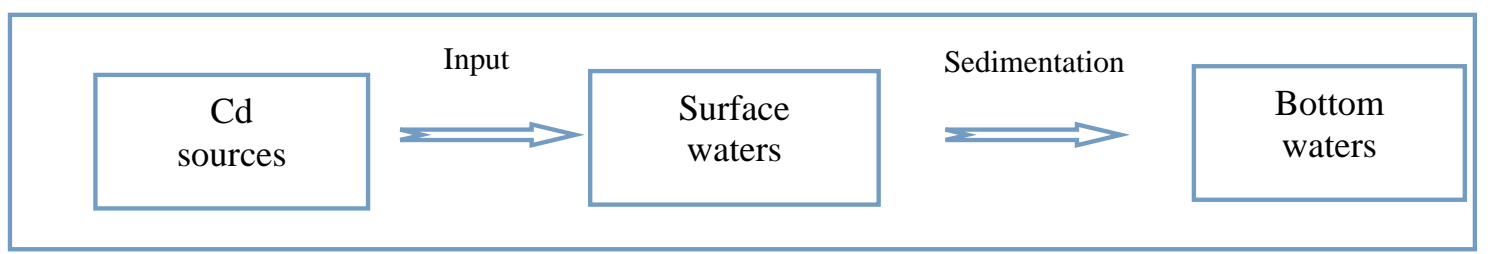

Fig. 2 Block diagram model of the three stages of Cd's vertical transporting process

\section{Conclusions}

Cd contents in bottom waters were strongly impacted by Cd contents in surface waters by means of vertical transporting, which was determined by water's effect that contained vertical water's effect and vertical water's effect. The vertical transporting process in waters in Jiaozhou Bay included three stages and six statuses. These stages and status were revealing the vertical transporting process of Cd clearly, and were essential to scientific research and environmental protection decision making. 


\section{Acknowledgments}

This research was sponsored by the China National Natural Science Foundation (31560107), Doctoral Degree Construction Library of Guizhou Nationalities University and Research Projects of Guizhou Nationalities University ([2014]02), Research Projects of Guizhou Province Ministry of Education (KY [2014] 266), Research Projects of Guizhou Province Ministry of Science and Technology (LH [2014] 7376).

\section{References}

[1] Yang DF and Miao ZQ: Marine Bay Ecology (I): Beijing, Ocean Precess, (2010), p. 1-320. (in Chinese)

[2] Yang DF and Gao ZH: Marine Bay Ecology (II): Beijing, Ocean Precess, (2010), p. 1-330. (in Chinese)

[3] Yang DF, Chen Y, Wang H, et al.: Coastal Engineering, Vol. 29 (2010), p. 73-82.

[4] Yang DF, Chen Y, Liu CX, et al.: Coastal Engineering, Vol. 32(2013), p. 68-78.

[5] Yang DF, Zhu SX, Wu YF, et al.: Applied Mechanics and Materials, Vol.644-650 (2014), p. 5325-5328.

[6] Yang DF, Wang FY, Wu YF, et al.: Applied Mechanics and Materials, Vol.644-650 (2014), p. 5329-5312.

[7] Yang DF. Chen Y, Gao ZH, et al.: Proceedings of the 2015 international symposium on computers and informatics. Vol. (2015), p. 2667-2674.

[8] Yang DF, Zhu SX, Yang XQ, et al.: Materials Engineering and Information Technology Apllication, Vol. (2015), p.558-561.

[9] Yang DF, Zhu SX, Wang FY, et al.: Advances in Computer Science Research, Vol. 2352(2015), p.194-197.

[10] Yang DF, Wang FY, Sun ZH, et al.: Advances in Engineering Research, Vol. 40(2015), p.776-781.

[11] Yang DF, Yang DF, Zhu SX, et al.: Advances in Engineering Research, Vol. Part B (2016), p. 403-407.

[12] Yang DF, Yang XQ, Wang M, et al.: Advances in Engineering Research. Vol. Part B (2016), p. 412-415.

[13] Yang DF, Chen Y, Gao ZH, et al.: Chinese Journal of Oceanology and Limnology, Vol. 23(2005), p. 72-90. (in Chinese)

[14] Yang DF, Wang FY, Gao ZH, et al. Marine Science, Vol. 28 (2004), p. 71-74. (in Chinese)

[15] China's State Oceanic Administration: The specification for marine monitoring (Ocean Press, Beijiang 1991), p.1-300. (in Chinese)

[16] Yang DF, Wang FY, Zhao XL, et al.: Sustainable Energy and Enviroment Protection, 2015, p.191-195.

[17] Yang DF, Wang FY, He HZ, et al.: Proceedings of the 2015 international symposium on computers and informatics, 2015, p. 2655-2660.

[18] Yang DF, Wang FY, Yang XQ, et al.: Advances in Computer Science Research, Vol. 2352 (2015), p. 198-204.

[19] Yang DF, Miao ZQ, Xu HZ, et al.: Ocean Development and Management, Vol. 30(2013), p. 46-50 (in Chinese).

[20] Yang DF, Wang FY, Zhu SX, et al.: Applied Mechanics and Materials, Vol. 651-653 (2014), p. 1415-1418. 